\title{
Experiences of Registered Nurses in the Transition to Healthcare Professionals: A Study from Military and Civilian Hospitals in Saudi Arabia
}

\author{
Dr. Mishal Aldaihani $\quad$ Dr. Mohammad Alrashidi $\quad$ Dr. Ali Alhaiti \\ Director of scholarship and training and education, Saudi. Public Authority for Applied Education and Training, \\ Kuwait. Education Consultant King Fahad Medical City, Saudi, PO Box 59046, Riyadh, 11525 Kingdom of \\ Saudi Arabia
}

\begin{abstract}
Registered nurses (RNs) often experience substantial job dissatisfaction and stress during the transition from a student to a healthcare professional. However, multicenter studies in this area are limited, and little is known whether the transition experience of RNs in a military hospital (MH) is different from that in civilian hospitals $(\mathrm{CH})$. This study presents a multicenter survey on the transition experiences of RNs and compares of transition experiences of RNs in $\mathrm{CH}$ and $\mathrm{MH}$. A multicenter survey was conducted in military and civilian hospitals in Saudi Arabia, using a modified version of the validated Casey-Fink Graduate Nurse Experience Survey. In the survey, 278 RNs participated. Of these, $71.2 \%$ were under 25 years of age, and 56\% were women. Approximately $36 \%$ of the respondents were from MH. A majority of RNs (89.9\%) cited fears related to patients' safety as a difficulty in the successful transition. When compared with RNs from $\mathrm{CH}$, a higher number of RNs from $\mathrm{MH}$ believed that improved orientation could be a support in transition (OR: 2.05, 95\% CI 1.23-3.43, P=0.008); conversely, a significantly lower number of respondents from $\mathrm{MH}$ believed that an improved work environment could be a support in transition (OR: $0.30,95 \%$ CI $0.16-0.55, \mathrm{P}=0.001$ ). Most RNs consider their fear for patients' safety as a difficult aspect of their transition experience. $\mathrm{RNs}$ in $\mathrm{MH}$ and $\mathrm{CH}$ have a different perception of the least satisfying aspect of their job.
\end{abstract}

Keywords: Transition experience, nurses, orientation, and work environment

DOI: $10.7176 / \mathrm{JBAH} / 11-6-03$

Publication date:March $31^{\text {st }} 2021$

\section{Introduction}

The transition of nurses from a student to a healthcare professional presents several challenges(Chick, Afaf, \& Meleis, 1985; Kumaran \& Carney, 2014). Gaps in theory and practice, inadequate mentorship, workplace bullying, and high workload are factors that make the transition difficult(Dyess \& Sherman, 2009; Spence Laschinger, Grau, Finegan, \& Wilk, 2012). It is known that a large number of nurses experience high stress and job dissatisfaction during the transition phase, and a significant fraction of nurses leave practice much early in their careers (Buchan \& Aiken, 2008). Considering the fact that the demand for nurses is increasing globally, and the functional requirements of practicing nurses are going to be more demanding, there is a need to understand the barriers/difficulties nurses experience during the transition(Ackerson \& Stiles, 2018; Juraschek, Zhang, Ranganathan, \& Lin, 2012).

The transition process from a student to a healthcare professional is multidimensional and is expected to induce some degree of stress as it generally involves (re)adjustments, unanticipated challenges(Adler \& Castro, 2019), and new interactions. The "transition phase" generally involves a relatively short duration, but it plays a formative role. A stressful transition, particularly in healthcare settings, can induce a host of inefficiencies, adversely affecting job satisfaction, retention, and patient safety(Kim \& Shin, 2020; Missen, McKenna, \& Beauchamp, 2014). A great deal of attention is being paid to identify factors that facilitate the smooth transition to a practicing nurse(Beattie, 1998; Flott \& Linden, 2016). At the professional level, in the transition period, registered nurses (RNs) feel inundated by myriad responsibilities, and the ambiguity, complexities, and stresses associated with a real healthcare setting make the transition further complex (Bakon et al., 2018; Beattie, 1998; Collard, Scammell, \& Tee, 2020; Cox, 2019; Fowler, Twigg, Jacob, \& Nattabi, 2018; Graf, Jacob, Twigg, \& Nattabi, 2020; Hayes, Bonner, \& Pryor, 2010). A phenomenological study on nurses' transition experiences revealed that nurses quickly adjust to the requirements of the new role(Delaney, 2003). This study also indicated that preceptors play a key role in the transition, and the sense of accomplishment in RNs is important for the successful transition. In the context of the difficulties observed during nurses' transition, the term "reality shock" is generally used(Graf et al., 2020; Sargis \& Kramer, 1975). This term denotes the possible mismatch between the expectations that nurses had as a student and the reality they faced in nursing practice at a hospital, covering various aspects related to human psychology, functional competence, financial constraints, and interpersonal relations(Bakon et al., 2018; Davey, 2002; Duchscher, 2008; Pennington \& Driscoll, 2019; Stulz, Francis, Pathrose, Sheehan, \& Drayton, 2021). 
Due to the adverse impact of negative transition experience on job satisfaction, attrition, functional competence, and patient safety, a significant amount of research has been conducted on understanding the transition experiences of RNs(Bakon et al., 2018; Butler \& Hardin-Pierce, 2005; Collard et al., 2020; Flott \& Linden, 2016; Stulz et al., 2021). However, most of the studies conducted on the transition experience of RNs were from civilian hospitals $(\mathrm{CH})$, and the transition experience of RNs in military hospitals $(\mathrm{MH})$ is not researched much(Cox, 2019; Moore, 2006); notably, though, the work environment and scope of practice are considerably different in $\mathrm{MH}$ and $\mathrm{CH}(\mathrm{Ma}$ et al., 2020). Psychological factors, competence, and patient management also differ considerably between these two settings(Alarcon, 2011). To the best of the authors' knowledge, there is no multicenter study reported previously, wherein transition experiences of $\mathrm{RNs}$ in $\mathrm{MH}$ and $\mathrm{CH}$ have been investigated.

This study reports the transition experience of graduate nurses in fourteen $\mathrm{MH}$ and $\mathrm{CH}$ in Saudi Arabia. Factors related to perceived difficulties and the impact of support in the transition were analyzed. The most satisfying and the least satisfying aspects of the work environment and the effect of the preceptorship program were examined. Furthermore, the differences between the transition experiences of RNs in $\mathrm{MH}$ and $\mathrm{CH}$ were analyzed.

\section{Methodology}

\subsection{Study Design and participants}

This survey on the various aspects of transition experiences of Saudi nurses was conducted in fourteen hospitals across the Kingdom of Saudi Arabia, namely: Prince Sultan Medical City, Wadi Al Dawasser Hospital, Prince Sultan Airbase Hospital, King Khalid Hospital, AlEman Hospital, Yamama Hospital, King Saud Medical City, Zelfi Hospital, Mohammad Bin Abdulaziz Hospital, and Al Karj Armed Forces Hospital, King Saud Hospital in Qaseem; Dammam Medical Complex in Eastern Province; Qesoma Hospital in HafrAl-Baten; and Najran Armed Forces Hospital. The University Human Research Ethics Committee granted approval to conduct the study (Approval no. 2014001195).

A sample size of 218 participants was determined to estimate moderate size effects at a $5 \%$ significance level with $80 \%$ power.

\subsection{SurveyInstrument}

A modified version of the validated Casey-Fink Graduate Nurse Experience Survey Tool was used(Casey, Fink, Krugman, \& Propst, 2004). This study was focused on the fifth part of the survey, comprising five questions on nurses' subjective experiences during their transition from a nursing student to a registered nurse. These questions include difficulties in the transition from the role of student to that of the registered nurse, strategies required to feel more supported, aspects of the work environment that are most satisfying, aspects of the work environment that are least satisfying, and comments and concerns about the preceptorship program. Translation of the survey instrument into Arabic was unnecessary since the participants could read, write and understand English. No names or personal identifying information were written on the questionnaire. The demographic information was not linked to the participants' information. The inclusion criteria were: more than 20 years old; minimum of two years experience in the ED as a nurse; and ability to read and comprehend English. The sealed boxes were distributed to the ED secretaries in the ED head offices of the participating hospitals.

\subsection{Statistical Analysis}

Both descriptive statistics and inferential statistics were conducted using the Statistical Package for the Social Sciences SPSS, Version 22.0 for Windows (IBM Corp, 2013). The missing data were removed from the analysis. The demographic data were summarized using descriptive statistics. Continuous variables were summarized using central tendency measures, mean and median with standard deviation. Categorical variables were described by using frequencies and percentages. The Odds ratio with the $\mathrm{MH}$ as the reference group and the Fisher's Exact Test of the association was used for the difficulty in transition scores, transition support, and work environment satisfaction. A p-value of less than 0.05 was considered statistically significant.

\section{Results}

\subsection{Demographics}

The survey forms were distributed to $350 \mathrm{RNs}$ in the ED of the participating hospitals. The final sample size was 278(response rate: 79.4\%); of these, 156 (56.1\%) were women. The majority of participants were under 25yearsofage ( $\mathrm{n}=198,71.2 \%)$. With respect to academic qualifications, $54 \%$ of the participants had a bachelor's degree in nursing, and the others had a diploma in nursing. A total of $216(77.7 \%)$ participants had internship experience, $31(11.2 \%)$ had worked as a nursing assistant, 27(9.7\%) worked as a volunteer, one (0.4\%) was EMT before current employment as an RN. Most participants reported that their orientation period lasted for 9-12 weeks $(n=245,88.1 \%)$. Notably, 119(42.8\%) participants had four or more preceptors, and 71(25.5\%) participants had 
zero to three preceptors.

\subsection{Perceived difficulty in transition}

In response to the question "What difficulties, if any, are you currently experiencing with the transition from the "student" role to the "RN" role?", an overwhelming number of respondents ( $\mathrm{n}=250,89.9 \%)$ cited fears related to the patients' safety as the difficulty in the successful transition (Table 1). The second frequent point identified as difficulty was related to orientation issues such as unit familiarization, learning technology, relationship with multiple preceptors, and information overload $(n=196,70.8 \%)$. Interestingly, only $46(16.6 \%)$ respondents identified a lack of confidence, and only 34 (12.3\%) respondents mentioned role expectations such as autonomy as difficulties in transition. When the responses were analyzed in $\mathrm{MH}$ and $\mathrm{CH}$ separately, a significant difference in the responses was observed in workload and orientational issues. A significantly lower number of patients in the $\mathrm{MH}$ group than in the $\mathrm{CH}$ group identified workload as difficulty (OR: $0.44,95 \% \mathrm{CI} 0.26-0.75, \mathrm{P}=0.003$ ). Conversely, more respondents in the $\mathrm{MH}$ group than in the $\mathrm{CH}$ group reported orientation-related issues (OR: 2.00, $95 \% \mathrm{CI} 1.22-3.31, \mathrm{P}=0.008$ ). There was no statistically significant difference between the $\mathrm{MH}$ and $\mathrm{CH}$ groups in terms of role expectations, lack of confidence, and fear of patient safety (Table 2).

\subsection{Role of support in the transition}

In response to the question "What could be done to help you feel more supported or integrated into the unit?", only $11.9 \%(n=33)$ of the respondents answered that unit socialization provided support during the transition. Increased support in the form of educator feedback and mentorship was identified by only $47(17.0 \%)$ RNs as help in feeling more supported in the transition period (Table 3). More than half of the respondents $(n=158,57.0 \%)$, however, reported that improved orientation could help in feeling more supported in transition and $30.7 \%(n=85)$ of the respondents believed that an improved work environment could be a support. A higher number of respondents from $\mathrm{MH}$ than those from $\mathrm{CH}$ believed that improved orientation is support in transition (OR: $2.05,95 \% \mathrm{CI} 1.23$ $3.43, \mathrm{P}=0.008$ ); however, a significantly lower number of respondents from $\mathrm{MH}$ than those from $\mathrm{CH}$ believed that an improved work environment could be of support in transition (OR: $0.30,95 \%$ CI $0.16-0.55, \mathrm{P}<0.001$, Table 4)

\subsection{Satisfying aspects of the work environment in transition}

For the query "What aspects of your work environment are most satisfying?", patients and families were identified as the most satisfying aspect of the work environment by $129(46.6 \%)$ respondents and the peer support by 106(38.3\%) respondents (Table 5). Positive work environment, professional learning role, and ongoing learning were considered satisfying by $21(7.6 \%), 15(5.4 \%)$, and $35(12.6 \%)$ of the respondents, respectively. The majority of the participants believed the least satisfying aspect was the orientation that involved inconsistent preceptors and lack of feedback $(n=164,59.2 \%)$. Only $10.8 \%$ of respondents believed that the interpersonal relationship was the least satisfying aspect, whereas the system and nursing work environment were reported by $79(28.5 \%)$ and 46 $(16.6 \%)$, respectively, as the least satisfying aspects. With respect to the most satisfying aspects of the transition, there was no significant difference between the respondents from $\mathrm{MH}$ and $\mathrm{CH}$. However, a significantly lower number of respondents from $\mathrm{MH}$ than those from $\mathrm{CH}$ identified the system as the least satisfying aspect (OR: 0.25 , 95\%CI 0.13-0.49, $\mathrm{P}<0.001)$. There was also a significant difference in the respondents from $\mathrm{MH}$ and $\mathrm{CH}$ with respect to the perceived importance of orientation. More respondents in the $\mathrm{MH}$ group than in the $\mathrm{CH}$ group believed orientation as the least satisfying aspect of the work environment (OR: 2.38, 95\%CI 1.40-4.02, $\mathrm{P}=0.001$, Table 6).

\section{Discussion}

Difficulties in the transition to clinical practice are major contributors to burnout and job dissatisfaction among graduate nurses during the early phase of their profession(Al Awaisi, Cooke, \& Pryjmachuk, 2015; Bakon et al., 2018; Casey et al., 2004; Dames, 2019; Duchscher, 2008; Jasper, 1996; Michalec, Diefenbeck, \& Mahoney, 2013; Phillips, Esterman, \& Kenny, 2015; Tower, Cooke, Watson, Buys, \& Wilson, 2015). This study was based on a multicentred survey in military and civilian hospitals in Saudi Arabia. Our study results indicated that most of the RNs did not identify the lack of confidence or role expectations as difficulties in the transition, and there were several critical differences between military and civilian RNs, with respect to their experiences in the transition to practice.

A majority of the RNs in this study acknowledged that their fear related to the safety of patients is a difficulty that adversely impacts the transition experience. Regarding this aspect, there was no significant difference between respondents from military and civilian hospitals. Military and civilian hospital settings are considerably different in terms of the scope of work and responsibilities(Elliott, Chargualaf, \& Patterson, 2017). Our findings, therefore, indicate the generalizability of fear related to the patients' safety in the transition phase of RNs. One of the factors that can explain the fear related to patients' safety could be the limited applicability of the expertise gained during nursing education to the real-world clinical setting(Collard et al., 2020). Nursing schools, though aiming to present 
a holistic knowledge of nursing, provide training in a relatively controlled environment under supervision(Flott \& Linden, 2016; Whitehead et al., 2013). However, the real-life clinical situation involves a significantly high degree of clinical complexity, unpredictability, and multifaceted interactions with clinicians, patients, and patients' family members. As a result, during the transition, RNs are likely exposed to complex and critical assignments, exceeding their skill sets gained as nursing students(Casey et al., 2004). The fear for the patient's safety is, therefore is on the expected lines. Indeed, this point can also be explained in the light of a phenomenon defined as 'sheltered student life'(Willman, Bjuresater, \& Nilsson, 2020; Woo \& Newman, 2020), highlighting the differences between anticipated work profiles as a student and real experiences as an RN. The high workload is a known stressor, particularly in the transition period(Duchscher, 2008; Labrague \& McEnroe-Petitte, 2018). A significantly higher number of respondents in civilian hospitals than in military hospitals reported workload as a difficulty in transition in our survey. Conversely, a higher number of nurses from military hospitals than those from civilian hospitals reported orientation issues as difficulty in transition. There was no difference in responses related to lack of confidence between $\mathrm{MH}$ and $\mathrm{CH}$ groups.

Surprisingly, in our study unit, socialization and increased support from managers were identified as the support in transition by only a minority of respondents. Our results, therefore, do not support the assertion that RNs consider socializing into their new working environment and culture as a major factor in their transition experience(Vanderspank-Wright, Lalonde, Smith, Wong, \& Bentz, 2019). Furthermore, factors related to improved work environment such as a gradual change in workload and assistance from unlicensed personals were identified by only $30 \%$ of respondents as supporting factors. When the responses were stratified in $\mathrm{MH}$ and $\mathrm{CH}$ groups, it was observed that a significantly lower number of respondents in $\mathrm{MH}$ believed that an improved work environment could support the transition. On the other hand, more respondents from the MH group claimed that improved orientation could support the transition. A minimal number of respondents revealed that factors related to ongoing learning, professional nursing role, and positive work environment are the most satisfying aspect of work. These findings indicated the role of workplace culture/environment as a source of stress and dissatisfaction(Butler \& Hardin-Pierce, 2005; Davey, 2002; Shinners, Africa, Deasy, \& Franqueiro, 2018). Previous research also suggested that in the hostile work environment, RNs were reluctant to ask for support/clarification due to the possibility of embarrassment(Mooney, 2007).

Realizing the adverse impact of the difficulties faced by nurses during their transition to practice, support programs are introduced in several hospitals(Duchscher, 2008; Flott \& Linden, 2016; Muir et al., 2013; Thomas, Bertram, \& Johnson, 2009). More than half of the respondents in our study claimed that factors related to an improved orientation such as preceptor support and consistency and unit-specific skills and practice support/help in the successful transition. These results echo the previous finding that improved orientation is an essential factor that favorably assists RNs in their transition(Ashley, Halcomb, Brown, \& Peters, 2018). In several other studies, preceptors' positive effect on the RNs' transition experience has been reported(Irwin, Bliss, \& Poole, 2018; Luhanga, Dickieson, \& Mossey, 2010; Muir et al., 2013). Preceptoring can be broadly defined as an approach to felicitate the transition between various roles, enabling RNs to effectively develop the necessary skills and confidence to achieve their professional goals(Fowler et al., 2018; Luhanga, Billay, Grundy, Myrick, \& Yonge, 2010; A. Ward \& McComb, 2017; A. E. Ward \& McComb, 2018). Interestingly, in our study, the least satisfying aspect was the improper orientation, i.e., inconsistent preceptors and lack of feedback. In previous studies , inconsistencies in preceptors' provision of support were reported to adversely affect the transition experience of RNs (Hayes et al., 2010; Irwin et al., 2018; Lewis \& McGowan, 2015; Luhanga, Dickieson, et al., 2010).

In our survey, making a difference in patients' lives and receiving positive feedback was identified by almost $50 \%$ of the RNs as the most satisfying aspect. There was no statistically significant difference between $\mathrm{MH}$ and $\mathrm{CH}$ groups in terms of the most satisfying work environment. However, a significantly lower number of respondents in the $\mathrm{MH}$ group than in the $\mathrm{CH}$ group mentioned the system as the least satisfying aspect of the work environment. A higher number of respondents from the $\mathrm{MH}$ group identified orientation as the least satisfying aspect. This finding corroborates earlier studies wherein knowledge and skill deficit were reported to seriously impact the morale of RNs(Adlam, Dotchin, \& Hayward, 2009; Clare \& Loon, 2003; Dearmun, 2000; Willman et al., 2020).

\section{Limitation}

This multicenter study has identified several factors that affect the transition experience of RNs. The main limitation of our study is that all medical hospitals included in the work are from Saudi Arabia; therefore, RNs in countries with different demographics, economic, and healthcare structures may have different transition experiences. The study is based on the survey; conducting prospective studies in this area will help identify the barriers to the successful transition.

\section{Conclusions}

Patients' safety is a major concern that affects the transition experience of RNs. In several aspects, the transition 
experiences of RNs in $\mathrm{MH}$ are different from those in $\mathrm{CH}$, underscoring a need to improve the currently used approaches to integrate nursing graduates with healthcare practice. Making nursing education more relevant to hospitals' functional requirements and introducing a comprehensive induction program can smoothen nurses' transition from academics to practice. During the early phase of the career, a cautious effort should also be made on training RNs to handle the workload effectively and maintain a good emotional state under stressful and demanding situations.

\section{Acknowledgment}

I am very grateful to the government of Saudi Arabia for supporting me and granting me a scholarship, and extend my thanks and gratitude to the editors of Editverse for their help in manuscript editing and formatting.

\section{Conflict of Interest}

The author declares that they have no conflict of interest.

\section{References}

Ackerson, K., \& Stiles, K. A. (2018). Value of Nurse Residency Programs in Retaining New Graduate Nurses and Their Potential Effect on the Nursing Shortage. J Contin Educ Nurs, 49(6), 282-288. doi:10.3928/0022012420180517-09

Adlam, K. A., Dotchin, M., \& Hayward, S. (2009). Nursing first year of practice, past, present and future: documenting the journey in New Zealand. $J$ Nurs Manag, 17(5), 570-575. doi:10.1111/j.13652834.2008.00932.x

Adler, A. B., \& Castro, C. A. (2019). Transitions: a Theoretical Model for Occupational Health and Wellbeing. Occupational Health Science, 3(2), 105-123. doi:10.1007/s41542-019-00043-3

Al Awaisi, H., Cooke, H., \& Pryjmachuk, S. (2015). The experiences of newly graduated nurses during their first year of practice in the Sultanate of Oman - A case study. Int J Nurs Stud, 52(11), 1723-1734. doi:10.1016/j.ijnurstu.2015.06.009

Alarcon, G. M. (2011). A meta-analysis of burnout with job demands, resources, and attitudes. J Vocat Behav, 79(2), 549-562. doi:10.1016/j.jvb.2011.03.007

Ashley, C., Halcomb, E., Brown, A., \& Peters, K. (2018). Experiences of registered nurses transitioning from employment in acute care to primary health care-quantitative findings from a mixed-methods study. $J$ Clin Nurs, 27(1-2), 355-362. doi:10.1111/jocn.13930

Bakon, S., Craft, J., Wirihana, L., Christensen, M., Barr, J., \& Tsai, L. (2018). An integrative review of graduate transition programmes: Developmental considerations for nursing management. Nurse Educ Pract, 28, 8085. doi:10.1016/j.nepr.2017.10.009

Beattie, H. (1998). Clinical teaching models: a review of the role of preceptor in the undergraduate nursing program. Aust J Adv Nurs, 15(4), 14-19.

Buchan, J., \& Aiken, L. (2008). Solving nursing shortages: a common priority. J Clin Nurs, 17(24), 3262-3268. doi:10.1111/j.1365-2702.2008.02636.x

Butler, K. M., \& Hardin-Pierce, M. (2005). Leadership strategies to enhance the transition from nursing student role to professional nurse. Nurs Leadersh Forum, 9(3), 110-117.

Casey, K., Fink, R., Krugman, M., \& Propst, J. (2004). The graduate nurse experience. J Nurs Adm, 34(6), 303311. doi:10.1097/00005110-200406000-00010

Chick, N., Afaf, I., \& Meleis, A. (1985). Transitions: A Nursing Concern. School of Nursing Departmental Papers.

Clare, J., \& Loon, A. v. (2003). Best practice principles for the transition from student to registered nurse. Collegian, 10(4), 25-31. doi:10.1016/s1322-7696(08)60073-6

Collard, S. S., Scammell, J., \& Tee, S. (2020). Closing the gap on nurse retention: A scoping review of implications for undergraduate education. Nurse Educ Today, 84, 104253. doi:10.1016/j.nedt.2019.104253

Cox, C. W. (2019). Military Students' Strengths and Challenges Based on Their Military Experiences: An Integrative Review. J Nurs Educ, 58(7), 392-400. doi:10.3928/01484834-20190614-03

Dames, S. (2019). The interplay of developmental factors that impact congruence and the ability to thrive among new graduate nurses: A qualitative study of the interplay as students transition to professional practice. Nurse Educ Pract, 36, 47-53. doi:10.1016/j.nepr.2019.02.013

Davey, L. (2002). Nurses eating nurses: the caring profession which fails to nurture its own! Contemp Nurse, 13(23), 192-197. doi:10.5172/conu.13.2-3.192

Dearmun. (2000). Supporting newly qualified staff nurses: the Lecturer Practitioner contribution. J Nurs Manag, 8(3), 159-165. doi:10.1046/j.1365-2834.2000.00164.x

Delaney, C. (2003). Walking a fine line: graduate nurses' transition experiences during orientation. J Nurs Educ, 42(10), 437-443. doi:10.3928/0148-4834-20031001-05

Duchscher, J. B. (2008). A process of becoming: the stages of new nursing graduate professional role transition. $J$ 
Contin Educ Nurs, 39(10), 441-450; quiz 451-442, 480. doi:10.3928/00220124-20081001-03

Dyess, S. M., \& Sherman, R. O. (2009). The first year of practice: new graduate nurses' transition and learning needs. J Contin Educ Nurs, 40(9), 403-410. doi:10.3928/00220124-20090824-03

Elliott, B., Chargualaf, K. A., \& Patterson, B. (2017). Military to civilian nurse: Personal and professional reconstruction. J Clin Nurs, 26(9-10), 1375-1384. doi:10.1111/jocn.13693

Flott, E. A., \& Linden, L. (2016). The clinical learning environment in nursing education: a concept analysis. $J$ Adv Nurs, 72(3), 501-513. doi:10.1111/jan.12861

Fowler, A. C., Twigg, D., Jacob, E., \& Nattabi, B. (2018). An integrative review of rural and remote nursing graduate programmes and experiences of nursing graduates. J Clin Nurs, 27(5-6), e753-e766. doi:10.1111/jocn.14211

Graf, A. C., Jacob, E., Twigg, D., \& Nattabi, B. (2020). Contemporary nursing graduates' transition to practice: A critical review of transition models. J Clin Nurs, 29(15-16), 3097-3107. doi:10.1111/jocn.15234

Hayes, B., Bonner, A., \& Pryor, J. (2010). Factors contributing to nurse job satisfaction in the acute hospital setting: a review of recent literature. J Nurs Manag, 18(7), 804-814. doi:10.1111/j.1365-2834.2010.01131.x

Irwin, C., Bliss, J., \& Poole, K. (2018). Does Preceptorship improve confidence and competence in Newly Qualified Nurses: A systematic literature review. Nurse Educ Today, 60, 35-46. doi:10.1016/j.nedt.2017.09.011

Jasper, M. (1996). The first year as a staff nurse: The experiences of a first cohort of Project 2000 nurses in a demonstration district. J Adv Nurs, 24, 779-790.

Juraschek, S. P., Zhang, X., Ranganathan, V., \& Lin, V. W. (2012). United States registered nurse workforce report card and shortage forecast. Am J Med Qual, 27(3), 241-249. doi:10.1177/1062860611416634

Kim, J. H., \& Shin, H. S. (2020). Exploring barriers and facilitators for successful transition in new graduate nurses: A mixed methods study. J Prof Nurs, 36(6), 560-568. doi:10.1016/j.profnurs.2020.08.006

Kumaran, S., \& Carney, M. (2014). Role transition from student nurse to staff nurse: facilitating the transition period. Nurse Educ Pract, 14(6), 605-611. doi:10.1016/j.nepr.2014.06.002

Labrague, L. J., \& McEnroe-Petitte, D. M. (2018). Job stress in new nurses during the transition period: an integrative review. Int Nurs Rev, 65(4), 491-504. doi:10.1111/inr.12425

Lewis, S., \& McGowan, B. (2015). Newly qualified nurses' experiences of a preceptorship. Br J Nurs, 24(1), 4043. doi:10.12968/bjon.2015.24.1.40

Luhanga, F. L., Billay, D., Grundy, Q., Myrick, F., \& Yonge, O. (2010). The one-to-one relationship: is it really key to an effective preceptorship experience? A review of the literature. Int J Nurs Educ Scholarsh, 7, Article21. doi:10.2202/1548-923X.2012

Luhanga, F. L., Dickieson, P., \& Mossey, S. D. (2010). Preceptor preparation: an investment in the future generation of nurses. Int J Nurs Educ Scholarsh, 7, Article38. doi:10.2202/1548-923X.1940

Ma, H., Chihava, T. N., Fu, J., Zhang, S., Lei, L., Tan, J., . . . Luo, Y. (2020). Competencies of military nurse managers: A scoping review and unifying framework. $J$ Nurs Manag, 28(6), 1166-1176. doi:10.1111/jonm. 13068

Michalec, B., Diefenbeck, C., \& Mahoney, M. (2013). The calm before the storm? Burnout and compassion fatigue among undergraduate nursing students. Nurse Educ Today, 33(4), 314-320. doi:10.1016/j.nedt.2013.01.026

Missen, K., McKenna, L., \& Beauchamp, A. (2014). Satisfaction of newly graduated nurses enrolled in transitionto-practice programmes in their first year of employment: a systematic review. J Adv Nurs, 70(11), 24192433. doi:10.1111/jan.12464

Mooney, M. (2007). Facing registration: the expectations and the unexpected. Nurse Educ Today, 27(8), 840-847. doi:10.1016/j.nedt.2006.11.003

Moore, C. (2006). The transition from student to qualified nurse: a military perspective. Br J Nurs, 15(10), 540542. doi:10.12968/bjon.2006.15.10.21128

Muir, J., Ooms, A., Tapping, J., Marks-Maran, D., Phillips, S., \& Burke, L. (2013). Preceptors' perceptions of a preceptorship programme for newly qualified nurses. Nurse Educ Today, 33(6), 633-638. doi:10.1016/j.nedt.2013.02.001

Pennington, G., \& Driscoll, A. (2019). Improving Retention of Home Health Nurses: Fostering Outcome Sustainability Through an Innovative Orientation and Mentorship Program. Home Healthc Now, 37(5), 256264. doi:10.1097/NHH.0000000000000782

Phillips, C., Esterman, A., \& Kenny, A. (2015). The theory of organisational socialisation and its potential for improving transition experiences for new graduate nurses. Nurse Educ Today, 35(1), 118-124. doi:10.1016/j.nedt.2014.07.011

Sargis, N., \& Kramer, M. (1975). Reality Shock: Why Nurses Leave Nursing. The American Journal of Nursing, 75(5), 891. doi:10.2307/3423480

Shinners, J., Africa, L., Deasy, P., \& Franqueiro, T. (2018). The Married State Approach to Precepting. J Contin Educ Nurs, 49(11), 514-518. doi:10.3928/00220124-20181017-08 
Spence Laschinger, H. K., Grau, A. L., Finegan, J., \& Wilk, P. (2012). Predictors of new graduate nurses' workplace well-being: testing the job demands-resources model. Health Care Manage Rev, 37(2), 175-186. doi:10.1097/HMR.0b013e31822aa456

Stulz, V., Francis, L., Pathrose, S., Sheehan, A., \& Drayton, N. (2021). Appreciative inquiry as an intervention to improve nursing and midwifery students transitioning into becoming new graduates: An integrative review. Nurse Educ Today, 98, 104727. doi:10.1016/j.nedt.2020.104727

Thomas, C. M., Bertram, E., \& Johnson, D. (2009). The SBAR communication technique: teaching nursing students professional communication skills. Nurse Educ, 34(4), 176-180. doi:10.1097/NNE.0b013e3181aaba54

Tower, M., Cooke, M., Watson, B., Buys, N., \& Wilson, K. (2015). Exploring the transition experiences of students entering into preregistration nursing degree programs with previous professional nursing qualifications: an integrative review. J Clin Nurs, 24(9-10), 1174-1188. doi:10.1111/jocn.12756

Vanderspank-Wright, B., Lalonde, M., Smith, C. A., Wong, S., \& Bentz, J. A. (2019). New Graduate Nurse Transition Into the Intensive Care Unit: Qualitative Insights From a Longitudinal Study-Part 1. Res Theory Nurs Pract, 33(4), 428-444. doi:10.1891/1541-6577.33.4.428

Ward, A., \& McComb, S. (2017). Precepting: A literature review. J Prof Nurs, 33(5), 314-325. doi:10.1016/j.profnurs.2017.07.007

Ward, A. E., \& McComb, S. A. (2018). Formalising the precepting process: A concept analysis of preceptorship. J Clin Nurs, 27(5-6), e873-e881. doi:10.1111/jocn.14203

Whitehead, B., Owen, P., Holmes, D., Beddingham, E., Simmons, M., Henshaw, L., . . . Walker, C. (2013). Supporting newly qualified nurses in the UK: a systematic literature review. Nurse Educ Today, 33(4), 370377. doi:10.1016/j.nedt.2013.01.009

Willman, A., Bjuresater, K., \& Nilsson, J. (2020). Newly graduated nurses' clinical competencies and need for further training in acute care hospitals. J Clin Nurs, 29(13-14), 2209-2220. doi:10.1111/jocn.15207

Woo, M. W. J., \& Newman, S. A. (2020). The experience of transition from nursing students to newly graduated registered nurses in Singapore. Int J Nurs Sci, 7(1), 81-90. doi:10.1016/j.ijnss.2019.11.002

Table 1. Perceived difficulties in the transition from student to registered nurse

\begin{tabular}{|c|c|c|c|}
\hline \multirow[t]{2}{*}{ Statement } & \multicolumn{2}{|c|}{ Difficulty in transition } & \multirow{2}{*}{$\begin{array}{l}\text { Total } \\
\text { n (\%)* }\end{array}$} \\
\hline & $\begin{array}{l}\text { Yes } \\
\mathrm{n}(\%)\end{array}$ & $\begin{array}{l}\text { No } \\
\text { n }(\%)\end{array}$ & \\
\hline $\begin{array}{l}\text { Role expectations (e.g., autonomy, more responsibility, being a } \\
\text { preceptor or in charge) }\end{array}$ & $34(12.3)$ & $243(87.7)$ & $277(100)$ \\
\hline $\begin{array}{l}\text { Lack of confidence (e.g., MD/PT communication skills, } \\
\text { delegation, knowledge deficit, critical thinking) }\end{array}$ & $46(16.6)$ & $231(83.4)$ & $277(100)$ \\
\hline $\begin{array}{l}\text { Workload (e.g., organizing, prioritizing, feeling overwhelmed, } \\
\text { ratios, patient acuity) }\end{array}$ & $105(37.9)$ & $172(62.1)$ & $277(100)$ \\
\hline Fears (e.g., patient safety) & $250(89.9)$ & $27(10.1)$ & $277(100)$ \\
\hline $\begin{array}{l}\text { Orientation issues (e.g., unit familiarization, learning technology, } \\
\text { relationship with multiple preceptors, information overload) }\end{array}$ & $196(70.8)$ & $81(29.2)$ & $277(100)$ \\
\hline
\end{tabular}

* One participant did not answer this section 
Table 2. Perceived difficulties in transition by hospital types

\begin{tabular}{|c|c|c|c|c|c|c|}
\hline Statement & $\begin{array}{c}\text { Difficulty in } \\
\text { transition }\end{array}$ & $\begin{array}{l}\mathrm{MH} \\
\mathrm{n}(\%)\end{array}$ & $\begin{array}{l}\mathrm{CH} \\
\mathrm{n}(\%)\end{array}$ & $\begin{array}{l}\text { Total } \\
\mathrm{n}(\%)\end{array}$ & $\begin{array}{c}\text { OR } \\
{ }^{a}(95 \% \mathrm{CI})\end{array}$ & P-value ${ }^{b}$ \\
\hline \multirow[t]{3}{*}{ Role expectation } & Yes & $7(7)$ & $27(15.3)$ & $34(12.3)$ & \multirow{3}{*}{$\begin{array}{c}0.42 \\
(0.18,1.00)\end{array}$} & \multirow[t]{3}{*}{0.056} \\
\hline & No & $93(93)$ & $150(84.7)$ & $243(87.7)$ & & \\
\hline & Total & $100(100)$ & $177(100)$ & $277(100)$ & & \\
\hline \multirow{3}{*}{$\begin{array}{l}\text { Lack of } \\
\text { confidence }\end{array}$} & Yes & $18(18)$ & $28(15.8)$ & $46(16.6)$ & \multirow{3}{*}{$\begin{array}{c}1.17 \\
(0.61,2.24)\end{array}$} & \multirow[t]{3}{*}{0.737} \\
\hline & No & $82(82)$ & $149(84.2)$ & $231(83.4)$ & & \\
\hline & Total & $100(100)$ & $177(100)$ & $277(100)$ & & \\
\hline \multirow[t]{3}{*}{ Workload } & Yes & $26(26)$ & $79(44.6)$ & $105(37.9)$ & \multirow{3}{*}{$\begin{array}{c}0.44 \\
(0.26,0.75)\end{array}$} & \multirow[t]{3}{*}{0.003} \\
\hline & No & $74(74)$ & $98(55.4)$ & $172(62.1)$ & & \\
\hline & Total & $100(100)$ & $177(100)$ & $177(100)$ & & \\
\hline \multirow[t]{3}{*}{ Fears } & Yes & $13(13)$ & $14(7.9)$ & $27(9.7)$ & \multirow{3}{*}{$\begin{array}{c}1.74 \\
(0.78,3.89)\end{array}$} & \multirow[t]{3}{*}{0.206} \\
\hline & No & $87(87)$ & $163(92.1)$ & $250(90.3)$ & & \\
\hline & Total & $100(100)$ & $177(100)$ & $277(100)$ & & \\
\hline \multirow[t]{3}{*}{ Orientation issues } & Yes & $102(87.0)$ & $94(58.0)$ & $196(70.8)$ & \multirow{3}{*}{$\begin{array}{c}2.00 \\
(1.22,3.31)\end{array}$} & \multirow[t]{3}{*}{0.008} \\
\hline & No & $15(12.0)$ & $66(41.0)$ & $81(29.2)$ & & \\
\hline & Total & $117(100)$ & $160(100)$ & $277(100)$ & & \\
\hline
\end{tabular}

${ }^{\mathrm{a}} \mathrm{OR}$ : Odds ratio, $\mathrm{MH}$ is the reference group

${ }^{\mathrm{b}}$ Fisher's exact test of association is considered statistically significant if the p-value is less than 0.05, MH: Military hospital, $\mathrm{CH}$ : Community hospital

Table 3. Potential activities helping RNs to feel more supported

\begin{tabular}{|c|c|c|c|c|}
\hline & Statement: & $\begin{array}{l}\text { Yes } \\
\mathrm{n}(\%)\end{array}$ & $\begin{array}{l}\text { No } \\
\mathrm{n}(\%)\end{array}$ & $\begin{array}{l}\text { Total } \\
\mathrm{n}(\%) *\end{array}$ \\
\hline \multirow[t]{4}{*}{ Support } & $\begin{array}{l}\text { Improved orientation (e.g., preceptor support and consistency, } \\
\text { orientation extension, unit specific skills practice) }\end{array}$ & $\begin{array}{c}158 \\
(57.0)\end{array}$ & $\begin{array}{l}119 \\
(43.0)\end{array}$ & $\begin{array}{l}277 \\
(100)\end{array}$ \\
\hline & $\begin{array}{l}\text { Increased support (e.g., manager, } \mathrm{RN} \text { and educator feedback and } \\
\text { support, mentorship) }\end{array}$ & $\begin{array}{c}47 \\
(17.0)\end{array}$ & $\begin{array}{l}230 \\
(83.0)\end{array}$ & $\begin{array}{l}277 \\
(100)\end{array}$ \\
\hline & $\begin{array}{l}\text { Unit socialization (e.g., being introduced to staff and MDs, } \\
\text { opportunities for staff socialization) }\end{array}$ & $\begin{array}{c}33 \\
(11.9)\end{array}$ & $\begin{array}{l}244 \\
(88.1)\end{array}$ & $\begin{array}{l}277 \\
(100)\end{array}$ \\
\hline & $\begin{array}{l}\text { Improved work environment (e.g., gradual ratio changes, more } \\
\text { assistance from } \\
\text { unlicensed personnel, involvement in schedule and committee } \\
\text { work) }\end{array}$ & $\begin{array}{c}85 \\
(30.7)\end{array}$ & $\begin{array}{l}192 \\
(69.3)\end{array}$ & $\begin{array}{l}277 \\
(100)\end{array}$ \\
\hline
\end{tabular}

* One participant did not answer this section 
Table 4. Transition support factor by hospital types

\begin{tabular}{|c|c|c|c|c|c|c|}
\hline Statement & $\begin{array}{l}\text { Difficulty in } \\
\text { transition }\end{array}$ & $\begin{array}{l}\mathrm{MH} \\
\mathrm{n}(\%)\end{array}$ & $\begin{array}{l}\mathrm{CH} \\
\mathrm{n}(\%)\end{array}$ & $\begin{array}{l}\text { Total } \\
\mathrm{n}(\%)\end{array}$ & $\begin{array}{l}\text { OR } \\
{ }^{a}(95 \% \mathrm{CI})\end{array}$ & $\begin{array}{l}\text { P- } \\
\text { value }^{b}\end{array}$ \\
\hline \multirow{3}{*}{$\begin{array}{l}\text { Improved } \\
\text { orientation }\end{array}$} & Yes & $68(68)$ & $90(50.8)$ & $158(57)$ & \multirow[t]{3}{*}{$2.05(1.23,3.43)$} & \multirow[t]{3}{*}{0.008} \\
\hline & No & $32(32)$ & $87(49.2)$ & $119(43)$ & & \\
\hline & Total & $100(100)$ & $177(100)$ & $277(100)$ & & \\
\hline \multirow{3}{*}{$\begin{array}{l}\text { Increased } \\
\text { support }\end{array}$} & Yes & $11(11)$ & $36(20.3)$ & $47(17.0)$ & \multirow[t]{3}{*}{$0.48(0.23,1.00)$} & \multirow[t]{3}{*}{0.066} \\
\hline & No & $89(89)$ & $141(79.7)$ & $230(83.0)$ & & \\
\hline & Total & $100(100)$ & $177(10)$ & $277(100)$ & & \\
\hline \multirow{3}{*}{$\begin{array}{l}\text { Unit } \\
\text { socialization }\end{array}$} & Yes & $16(16)$ & $17(9.6)$ & $33(11.9)$ & \multirow{3}{*}{$\begin{array}{l}1.79(0.86, \\
3.73)\end{array}$} & \multirow[t]{3}{*}{0.084} \\
\hline & No & $84(84)$ & $160(90.4)$ & $244(88.1)$ & & \\
\hline & Total & $100(100)$ & $177(100)$ & $277(100)$ & & \\
\hline \multirow{3}{*}{$\begin{array}{l}\text { Improved work } \\
\text { environment }\end{array}$} & Yes & $16(16)$ & 69 (39) & $85(30.7)$ & \multirow{3}{*}{$\begin{array}{l}0.30(0.16, \\
0.55)\end{array}$} & \multirow[t]{3}{*}{$<0.001$} \\
\hline & No & $84(84)$ & $108(61)$ & $192(69.3)$ & & \\
\hline & Total & $100(100)$ & $177(100)$ & $277(100)$ & & \\
\hline
\end{tabular}

${ }^{\text {a }}$ OR: Odds ratio, $\mathrm{MH}$ is the reference group

${ }^{\mathrm{b}}$ Fisher's exact test of association is considered statistically significant if the p-value is less than $0.05 \mathrm{MIH}$ : Military hospital, $\mathrm{MH}$ : Military hospital, $\mathrm{CH}$ : Community hospital

Table 5. Most satisfying and least satisfying aspects of the work environment

\begin{tabular}{|c|c|c|c|c|}
\hline & $\begin{array}{l}\text { Statement of most/least satisfying aspects of work } \\
\text { environment }\end{array}$ & $\begin{array}{l}\text { Yes } \\
\mathrm{n}(\%)\end{array}$ & $\begin{array}{l}\text { No } \\
n(\%)\end{array}$ & $\begin{array}{l}\text { Total } \\
\mathrm{n}(\%)^{*}\end{array}$ \\
\hline \multirow[t]{5}{*}{$\begin{array}{l}\text { Most satisfying aspects of } \\
\text { the work environment }\end{array}$} & $\begin{array}{l}\text { Peer support (e.g., belonging, team approach, } \\
\text { helpful and friendly staff) }\end{array}$ & $\begin{array}{c}106 \\
(38.3)\end{array}$ & $\begin{array}{l}171 \\
(61.7)\end{array}$ & $\begin{array}{l}277 \\
(100)\end{array}$ \\
\hline & $\begin{array}{l}\text { Patients and families (e.g., making a difference, } \\
\text { positive feedback, patient satisfaction, patient } \\
\text { interaction) }\end{array}$ & $\begin{array}{c}129 \\
(46.6)\end{array}$ & $\begin{array}{l}148 \\
(53.4)\end{array}$ & $\begin{array}{l}277 \\
(100)\end{array}$ \\
\hline & $\begin{array}{l}\text { Ongoing learning (e.g., preceptors, unit role } \\
\text { models, mentorship) }\end{array}$ & $\begin{array}{c}35 \\
(12.6)\end{array}$ & $\begin{array}{l}242 \\
(87.4)\end{array}$ & $\begin{array}{l}277 \\
(100)\end{array}$ \\
\hline & $\begin{array}{l}\text { Professional nursing role (e.g., challenge, } \\
\text { benefits, fast pace, critical thinking, } \\
\text { empowerment) }\end{array}$ & $\begin{array}{c}15 \\
(5.4) \\
\end{array}$ & $\begin{array}{l}262 \\
(94.2)\end{array}$ & $\begin{array}{l}277 \\
(100)\end{array}$ \\
\hline & $\begin{array}{l}\text { Positive work environment (e.g., good ratios, } \\
\text { available resources, great facility, up-to-date } \\
\text { technology) }\end{array}$ & $\begin{array}{c}21 \\
(7.6)\end{array}$ & $\begin{array}{l}256 \\
(92.4)\end{array}$ & $\begin{array}{l}277 \\
(100)\end{array}$ \\
\hline \multirow[t]{4}{*}{$\begin{array}{l}\text { Least satisfying aspects of } \\
\text { the work environment }\end{array}$} & $\begin{array}{l}\text { Nursing work environment (e.g., unrealistic } \\
\text { ratios, tough schedule, futility of care) }\end{array}$ & $\begin{array}{c}46 \\
(16.6)\end{array}$ & $\begin{array}{l}231 \\
(83.4)\end{array}$ & $\begin{array}{l}277 \\
(100)\end{array}$ \\
\hline & $\begin{array}{l}\text { System (e.g., outdated facilities and equipment, } \\
\text { small workspace, charting, paperwork) }\end{array}$ & $\begin{array}{c}79 \\
(28.5)\end{array}$ & $\begin{array}{l}198 \\
(71.5)\end{array}$ & \\
\hline & $\begin{array}{l}\text { Interpersonal relationships (e.g., gossip, lack of } \\
\text { recognition, lack of teamwork, politics) }\end{array}$ & $\begin{array}{c}30 \\
(10.8)\end{array}$ & $\begin{array}{l}247 \\
(89.2)\end{array}$ & $\begin{array}{l}277 \\
(100)\end{array}$ \\
\hline & $\begin{array}{l}\text { Orientation (inconsistent preceptors, lack of } \\
\text { feedback) }\end{array}$ & $\begin{array}{c}164 \\
(59.2)\end{array}$ & $\begin{array}{l}113 \\
(40.8)\end{array}$ & $\begin{array}{l}277 \\
(100)\end{array}$ \\
\hline
\end{tabular}

* One participant did not answer this section 
Table 6. Most/least satisfying aspects of work environment by hospital types

\begin{tabular}{|c|c|c|c|c|c|c|}
\hline Transition aspect & Statement & MH (\%) & $\mathrm{CH}(\%)$ & Total $(\%)$ & $\begin{array}{c}\mathrm{OR}^{a} \\
(95 \% \mathrm{CI})\end{array}$ & P-value ${ }^{b}$ \\
\hline \multicolumn{7}{|c|}{ Work environment (most satisfied) } \\
\hline Peer support & $\begin{array}{l}\text { Yes } \\
\text { No } \\
\text { Total }\end{array}$ & $\begin{array}{c}35(35) \\
65(65) \\
100(100)\end{array}$ & $\begin{array}{c}71(40.1) \\
106(59.9) \\
177(100)\end{array}$ & $\begin{array}{l}106(38.3) \\
171(61.7) \\
277(100)\end{array}$ & $\begin{array}{c}0.80 \\
(0.48,1.33)\end{array}$ & 0.441 \\
\hline $\begin{array}{l}\text { Patients and } \\
\text { families }\end{array}$ & $\begin{array}{l}\text { Yes } \\
\text { No } \\
\text { Total } \\
\end{array}$ & $\begin{array}{c}44(44) \\
56(56) \\
100(100) \\
\end{array}$ & $\begin{array}{c}85(48) \\
92(52) \\
177(100) \\
\end{array}$ & $\begin{array}{l}129(46.6) \\
148(53.4) \\
277(100)\end{array}$ & $\begin{array}{c}0.85 \\
(0.52,1.39)\end{array}$ & 0.533 \\
\hline Ongoing learning & $\begin{array}{l}\text { Yes } \\
\text { No } \\
\text { Total }\end{array}$ & $\begin{array}{c}16(16) \\
84(84) \\
100(100) \\
\end{array}$ & $\begin{array}{c}19(10.7) \\
158(89.3) \\
177(100) \\
\end{array}$ & $\begin{array}{c}35(12.6) \\
242(87.4) \\
277(100) \\
\end{array}$ & $\begin{array}{c}1.58 \\
(0.77,3.24)\end{array}$ & 0.258 \\
\hline $\begin{array}{l}\text { Professional } \\
\text { nursing role }\end{array}$ & $\begin{array}{l}\text { Yes } \\
\text { No } \\
\text { Total }\end{array}$ & $\begin{aligned} 9(9) \\
91(91) \\
100(100)\end{aligned}$ & $\begin{array}{c}6(3.4) \\
171(96.6) \\
177(100) \\
\end{array}$ & $\begin{array}{c}15(5.4) \\
262(94.6) \\
277(100) \\
\end{array}$ & $\begin{array}{c}2.82 \\
(0.97,8.17)\end{array}$ & 0.056 \\
\hline $\begin{array}{l}\text { Positive work } \\
\text { environment }\end{array}$ & $\begin{array}{l}\text { Yes } \\
\text { No } \\
\text { Total }\end{array}$ & $\begin{array}{c}7(7) \\
93(93) \\
100(100) \\
\end{array}$ & $\begin{array}{c}14(7.9) \\
163(92.1) \\
177(100) \\
\end{array}$ & $\begin{array}{c}21(7.6) \\
256(92.4) \\
277(100) \\
\end{array}$ & $\begin{array}{c}0.87 \\
(0.34,2.25)\end{array}$ & 0.820 \\
\hline \multicolumn{7}{|c|}{ Work environment (least satisfied) } \\
\hline $\begin{array}{l}\text { Nursing work } \\
\text { environment }\end{array}$ & $\begin{array}{l}\text { Yes } \\
\text { No } \\
\text { Total } \\
\end{array}$ & $\begin{array}{c}12(12) \\
88(88) \\
100(100) \\
\end{array}$ & $\begin{array}{c}34(19.2) \\
143(80.8) \\
177(100) \\
\end{array}$ & $\begin{array}{c}46(16.6) \\
321(83.4) \\
277(100) \\
\end{array}$ & $\begin{array}{c}0.57 \\
(0.28,1.17)\end{array}$ & 0.133 \\
\hline System & $\begin{array}{l}\text { Yes } \\
\text { No } \\
\text { Total }\end{array}$ & $\begin{array}{c}13(13) \\
87(87) \\
100(100)\end{array}$ & $\begin{array}{c}66(37.3) \\
111(62.7) \\
177(100)\end{array}$ & $\begin{array}{c}79(28.5) \\
198(7105) \\
277(100)\end{array}$ & $\begin{array}{c}0.25 \\
(0.13,0.49)\end{array}$ & $<0.001$ \\
\hline $\begin{array}{l}\text { Interpersonal } \\
\text { relationships }\end{array}$ & $\begin{array}{l}\text { Yes } \\
\text { No } \\
\text { Total }\end{array}$ & $\begin{array}{c}15(15) \\
85(85) \\
100(100)\end{array}$ & $\begin{array}{c}15(8.5) \\
162(91.5) 177 \\
(100)\end{array}$ & $\begin{array}{c}30(10.8) \\
247(89.8) 277 \\
(100)\end{array}$ & $\begin{array}{c}1.90 \\
(0.89,4.09)\end{array}$ & 0.109 \\
\hline \multirow[t]{3}{*}{ Orientation } & Yes & $72(72)$ & $92(52)$ & $164(59.2)$ & 2.38 & 0.001 \\
\hline & No & $28(28)$ & $85(48)$ & $113(40.8)$ & $(1.40,4.02)$ & \\
\hline & Total & $100(100)$ & $177(100)$ & $277(100)$ & & \\
\hline
\end{tabular}

a OR: Odds ratio, $\mathrm{MH}$ is the reference group

${ }^{b}$ Fisher's exact test of association is considered statistically significant if the p-value is less than 0.05

MH: Military hospital, $\mathrm{CH}$ : Community hospital 